\title{
Cost Comparison for REDC Pretreatment Project
}

\author{
S. M. Robinson \\ F. J. Homan
}

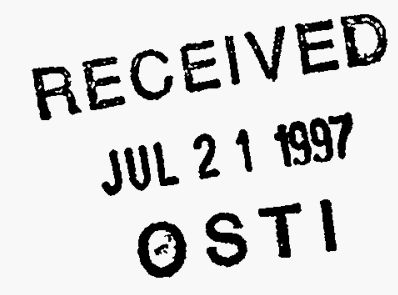


This report has been reproduced directly from the best available copy.

Available to DOE and DOE contractors from the Office of Scientific and Technical Information, P. O. Box 62, Oak Ridge, TN 37831; prices available from (423) 576-8401, FTS 626-8401.

Available to the public from the National Technical Information Service, U.S. Department of Commerce, 5285 Port Royal Road, Springfield, VA 22161.

This report was prepared as an account of work sponsored by an agency of the United States Government. Neither the United States Government nor any agency thereof, nor any of their employees, makes any warranty, express or implied, or assumes any legal liability or responsibility for the accuracy, completeness, or usefulness of any information, apparatus, product, or process disclosed, or represents that its use would not infringe privately owned rights. Reference herein to any specific commercial product, process, or service by trade name, trademark, manufacturer, or otherwise, does not necessarily constitute or imply its endorsement, recommendation, or favoring by the United States Government or any agency thereof. The views and opinions of authors expressed herein do not necessarily state or reflect those of the United States Government of any agency thereof. 


\section{DISCLAIMER}

Portions of this document may be illegible electronic image products. Images are produced from the best available original document. 
Chemical Technology Division

COST COMPARISON FOR REDC PRETREATMENT PROJECT

\section{S. M. Robinson}

F. J. Homan*

*Molten Metal Technology, Inc., Oak Ridge, Tenn.

Date of Issue — June 1997

Prepared by the OAK RIDGE NATIONAL LABORATORY

Oak Ridge, Tennessee 37831 managed by

LOCKHEED MARTIN ENERGY RESEARCH CORP.

for the

U.S. DEPARTMENT OF ENERGY

under contract DE-AC05-96OR22464 


\section{CONTENTS \\ 1}

\section{Page}

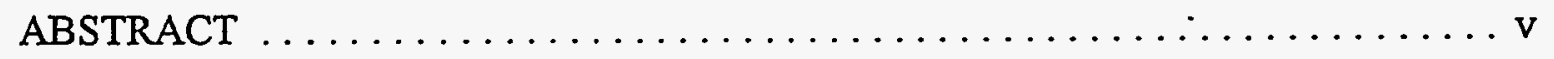

1. BACKGROUND $\ldots \ldots \ldots \ldots \ldots \ldots \ldots \ldots \ldots \ldots \ldots \ldots \ldots \ldots \ldots \ldots \ldots \ldots \ldots$

2. ASSUMPTIONS $\ldots \ldots \ldots \ldots \ldots \ldots \ldots \ldots \ldots \ldots \ldots \ldots \ldots \ldots \ldots \ldots \ldots$

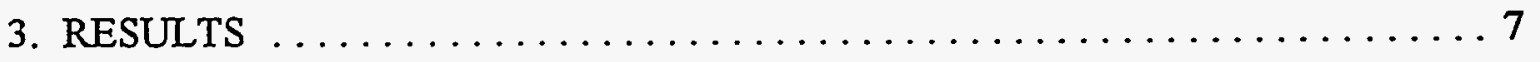

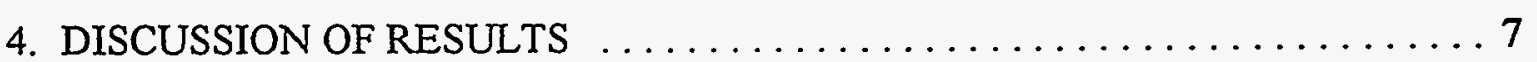

5. RECOMMENDATION $\ldots \ldots \ldots \ldots \ldots \ldots \ldots \ldots \ldots \ldots \ldots \ldots \ldots \ldots \ldots \ldots$

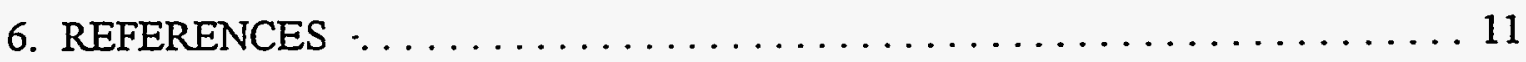


. . 


\begin{abstract}
This analysis has been prepared to support the planned expenditure to provide the Radiochemical Engineering Development Center (REDC) with the capability to pretreat their liquid low-level waste (LLLW) before discharging it to the Oak Ridge National Laboratory (ORNL) LLLW system. Pretreatment will remove most of the radioactivity, particularly the transuranic isotopes and Cs-137 from the waste to be discharged. This will render the supernates that accumulate in the storage tanks low-activity Class B low-level wastes rather than highactivity Class $\mathrm{B}$ or Class $\mathrm{C}$ wastes. The sludges will be Class $\mathrm{C}$ rather than remote-handled transuranic (RH-TRU) wastes.

When REDC wastes are comingled with other ORNL LLLW, the present-worth treatment and transport costs are higher by a factor of 1.3 for the "no-pretreatment" cases. This result is consistent with data from similar studies conducted at other sites.

Based on the information presented in this analysis, our recommendation is to proceed with REDC treatment projects.
\end{abstract}




\section{BACKGROUND}

This analysis has been prepared to support the planned expenditure to provide the Radiochemical Engineering Development Center (REDC) with the capability to pretreat their liquid low-level waste (LLLW) before discharging it to the Oak Ridge National Laboratory (ORNL) LLLW system. Pretreatment will remove most of the radioactivity, particularly the transuranic isotopes and Cs- 137 from the waste to be discharged. This will render the supernates that accumulate in the storage tanks low-activity Class B low-level wastes rather than highactivity Class B or Class $\mathbf{C}$ wastes. The sludges will be Class $\mathrm{C}$ rather than remote-handled transuranic (RH-TRU) wastes.

In addition to the financial advantages afforded by pretreatment, as outlined in this study, there are also regulatory advantages. ORNL has committed to the Tennessee Department of Environment and Conservation (TDEC) that no TRU sludges will be accumulated in the new storage tanks. Implementation of the pretreatment project is the most cost-effective way to honor this commitment.

\section{ASSUMPTIONS}

- REDC pretreatment project costs will total approximately $\$ 6.5$ million.

- REDC's annual expenditure for waste management activities, about $\$ 2$ million, will not be influenced by the pretreatment project. It will cost about the same to pretreat or to discharge directly to the LLLW system. This assumption is preliminary and may require additional review; however, it has been validated by the REDC staff.

- The waste volume data shown in Table 1 will be valid for the period of study. This is a conservative assumption because some one-time generations occurred during 1995 at buildings other than REDC.

- REDC generates 15,000 gal per year of dilute LLLW containing $10,102 \mathrm{Ci}$ of activity. Evaporation reduces this volume to 1700 gal of $95 \%$ supernate and $5 \%$ sludge.

- REDC pretreatment will result in (1) a dry salt cake containing 9,926 Ci in $11 \mathrm{gal}$ and (2) $15,000 \mathrm{gal}$ of dilute LLLW containing $175 \mathrm{Ci}$. This volume of LLLW will be reduced to $1,690 \mathrm{gal}$ of $100 \%$ supernate by evaporation. The resins used in the REDC pretreatment system will be regenerated each time the column is loaded with cesium. Each column can be regenerated approximately six times before the resin becomes exhausted and must be replaced. It is estimated that 1 gal of exhausted resin will require disposal each year. Approximately twice per year the regenerated resin will be transferred to a disposal container, dewatered, and disposed of as solid LLLW on site. 
Table 1. Summary of LLLW generation during 1995

\begin{tabular}{|c|c|c|c|c|c|c|}
\hline $\operatorname{Tank}(s)$ & $\begin{array}{l}\text { Activities that } \\
\text { generate LLLW }\end{array}$ & Generatorfaclility & $\begin{array}{c}\text { Dilute generation } \\
\text { (gal/year) }\end{array}$ & $\begin{array}{l}\text { Concentrate } \\
\text { generation } \\
\text { (gallyear) }\end{array}$ & Isotope & $\frac{\operatorname{sent}}{\text { cliyear }}$ \\
\hline WC-10 & $\begin{array}{l}\text { Docontamination and maintonanco of hot } \\
\text { colls }\end{array}$ & $\begin{array}{l}\text { Bidgs, 3028, 2020, 3030-32, 3038, 3039, } \\
3047,3093\end{array}$ & 1,800 & $<100$ & Varlous & Trace \\
\hline WC-18 & Regeneration of lon-exchango column & Bldgs, 3001(OGR), 3042(ORR), 3148(BSR) & 2,400 & $<50$ & Varlous & Traco \\
\hline 2020 & Analytical sampling and research & Bldg. 2026 & 2,300 & $<50$ & Various & Trace \\
\hline WC.20 & $\begin{array}{l}\text { C-252 separation and purfification for } \\
\text { uso in nuclear modicino, defonso. } \\
\text { relatod applications; transplutonlum } \\
\text { radlonuclldes for worldwidio research }\end{array}$ & Bidg. 7920,7830 (REDC) & 15,000 & 1,700 & $\begin{array}{l}\text { Am-241,-243 } \\
\text { Mixod Pu } \\
\text { Cm-244,-245,-246 } \\
\text { CC.250,-252 } \\
\text { MFPP }\end{array}$ & $\begin{array}{c}1.2 \\
19.6 \\
81 \\
0.6 \\
10,000\end{array}$ \\
\hline HFIR & $\begin{array}{l}\text { Irradlation of specimens to produco } \\
\text { olements thal aro purifiod at REDCC }\end{array}$ & Bldg. 7800 (HFIR) & 100,000 & 1,500 & $\begin{array}{l}\mathrm{H} \cdot 3 \\
\mathrm{Na}-24 \\
\mathrm{Mg}-27 \\
\mathrm{C} \cdot 51 \\
\mathrm{C}-00 \\
\mathrm{~W}-181 \\
\mathrm{~W}-187 \\
\end{array}$ & $\begin{array}{c}4 \\
308 \\
22 \\
84 \\
8 \\
808 \\
4\end{array}$ \\
\hline WC-3 & Motal pollshing & Bidg. 3025 & 750 & $<50$ & Various & Trace \\
\hline W.22 & $\begin{array}{l}\text { Filush water, troatment of off-gas; } \\
\text { treatment of procoss wasto }\end{array}$ & $\begin{array}{l}\text { PWTP } \\
3030 \text { Stack }\end{array}$ & $\begin{array}{l}10,800 \\
44,000\end{array}$ & $\begin{array}{c}10,600 \\
100\end{array}$ & \begin{tabular}{|l|} 
Varlous \\
Various
\end{tabular} & $\begin{array}{l}\text { Trace } \\
\text { Trace }\end{array}$ \\
\hline N.71 & Research & Bidg. 3018 & 420 & $<100$ & $\overline{P u-238}$ & 0.6 \\
\hline Truckod & $\begin{array}{l}\text { Ropail and malntenance of manlpulators. } \\
\text { Metal polishing and oxtondod docon- } \\
\text { tamination during } 1895 \\
\text { NOTE: In } 1 \text { out of } 12 \text { samplo analysos, } \\
0.0007 \text { Cl of Am-243 was dotectod in a } \\
\text { batch. Thls facllty doos not currontly handlo } \\
\text { TRU isotopos, and this is considerod } \\
\text { a rosult of historical work at this facillty. }\end{array}$ & $\begin{array}{l}\text { 8ldg. } 3074 \\
\text { Bldg. } 3525\end{array}$ & $\begin{array}{l}1,500 \\
15,000\end{array}$ & $\begin{array}{l}<50 \\
100\end{array}$ & $\begin{array}{l}\text { Various } \\
\text { Fo-58 } \\
\text { Cr-51 } \\
\text { Co-60 } \\
N \text { Nb-95 } \\
\text { Zr-95 } \\
\text { Cs-134 } \\
C_{s-137} \\
C_{0-144} \\
\text { Eu-152, } 153,-154 \\
\text { Ir-192 }\end{array}$ & $\begin{array}{c}\text { Traco } \\
20 \\
1,300 \\
4 \\
1 \\
2 \\
20 \\
200 \\
9 \\
31 \\
200\end{array}$ \\
\hline Bottlod & Resoarch & $\begin{array}{l}\text { Bidg. } 1505,3047,3592,4500 N, 45005,4501, \\
4500,5505\end{array}$ & 200 & $<50$ & Various & Trace \\
\hline $\begin{array}{l}\text { WC-2, }, 3,-5,-6,-8,-8,-10,-11,-12,-13 \\
14,-18 ; W-1 A,-12,-16,-17 ; \text { HFIR; } \\
\text { S-523,-324,-223 }\end{array}$ & $\begin{array}{l}\text { Nonprogremmatio Inleakego; sumps; } \\
\text { filtor pits, otc. }\end{array}$ & & 227,600 & 800 & Vartous & Trace \\
\hline$T H-4, W \cdot 3, W \cdot-8, W \cdot 8$ & Inactivo tank wasto & & 187,000 & 4,500 & $\begin{array}{l}C 0-60 \\
\text { Sir }-80 \\
\text { Cr-137 } \\
\text { Eu-152, -154, -155 }\end{array}$ & $\begin{array}{c}3 \\
22 \\
530 \\
2\end{array}$ \\
\hline \multicolumn{3}{|l|}{ Totals } & 689.070 & 22,600 & & 14,633 \\
\hline
\end{tabular}

- Within the group of reactors listed In the prevlous column, only tho OGR eurrontly generates LLLW.

b Thls is only the emeunt ef dilluto PWTP wasto sent to the evaporator. Concentrato number also includes wasto sent directly to W.21.

c Tank W-12 was used by Bidg. 3525 for dlsposal of LLLW duting 1995. 
- The entire ORNL complex generates 589,070 gal of dilute LLLW containing $14,633 \mathrm{Ci}$ of activity (10,102 $\mathrm{Ci}$ from REDC). Evaporation reduces this volume to $22,600 \mathrm{gal}$ of $95 \%$ supernate and $5 \%$ sludge.

- Waste treatment flow sheets are shown in Figs. 1 and 2.

- Figure 1 shows the annual REDC waste generation rates if the REDC waste could be segregated from the remainder of ORNL's LLLW. It should be noted that REDC waste cannot be physically segregated from the existing LLLW system without significant upgrades, which are not included in this cost estimate. Figure 1 is shown only to compare the relative impact that REDC waste has on the overall LLLW system (Fig. 2).

- Figure 2 shows the annual ORNL LLLW system waste generation rates with and without REDC pretreatment.

- The curie removal efficiencies by pretreatment operations are estimates. More accurate information will not be available until operational experience has been obtained.

- Final waste forms without pretreatment are

- high-activity Class B cement from a liquid waste solidification project (LWSP)type treatment of supernates for disposal at the Nevada Test Site (NTS), and

- RH-TRU cement or glass from a sludge treatment operation for disposal at the Waste Isolation Pilot Plant (WIPP).

- Final waste forms after REDC pretreatment are

- low-activity Class B cement from LWSP-type supernate treatment operations for disposal at NTS,

- Class C cement or glass from sludge treatment operations for disposal at NTS,

- Class A cement or glass from solidification of regenerated REDC resins for on-site disposal, and

- RH-TRU cement or glass from fixation of the small volume of salt cake from the REDC pot dryer or evaporator for disposal at a high-level waste repository.

- Volume changes due to solidification will vary, depending on waste formulation and waste loading. Actual values will not be available until waste formulation studies have been completed. Midrange values were chosen for these estimates. Ratios of treated volumes to original volumes can be summarized as follows: 1:1 for glass solidification of sludge, 1.7:1 for grout solidification of supernate, and 3:1 for grout solidification of sludge.

- Waste will be accumulated for 16 years before treatment to be consistent with TRU waste treatment planning. ${ }^{1}$ This may not be a valid assumption since more frequent treatment will probably be required. However, the cost trends would be the same even if more frequent treatment of wastes was scheduled. 


\section{Without}

Pretreatment

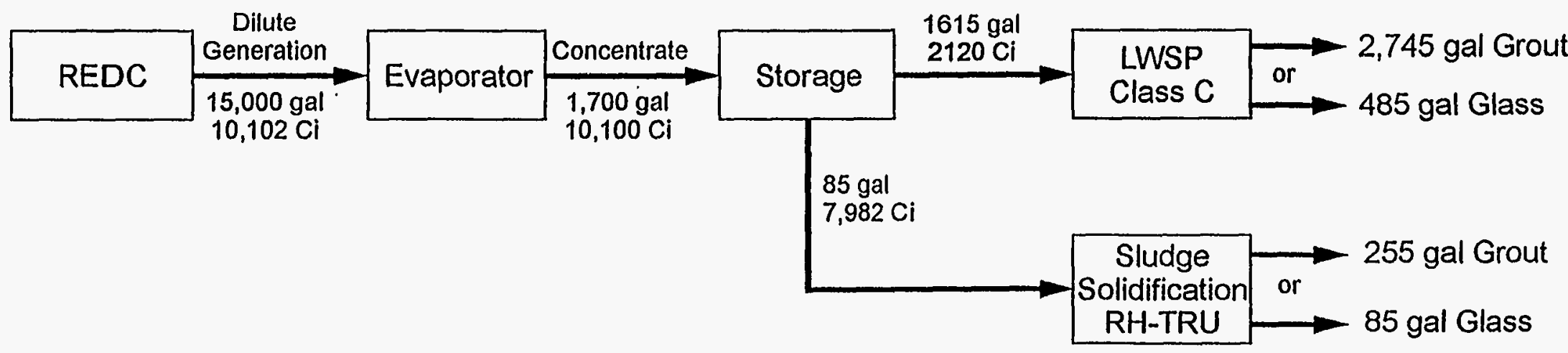

With

Pretreatment

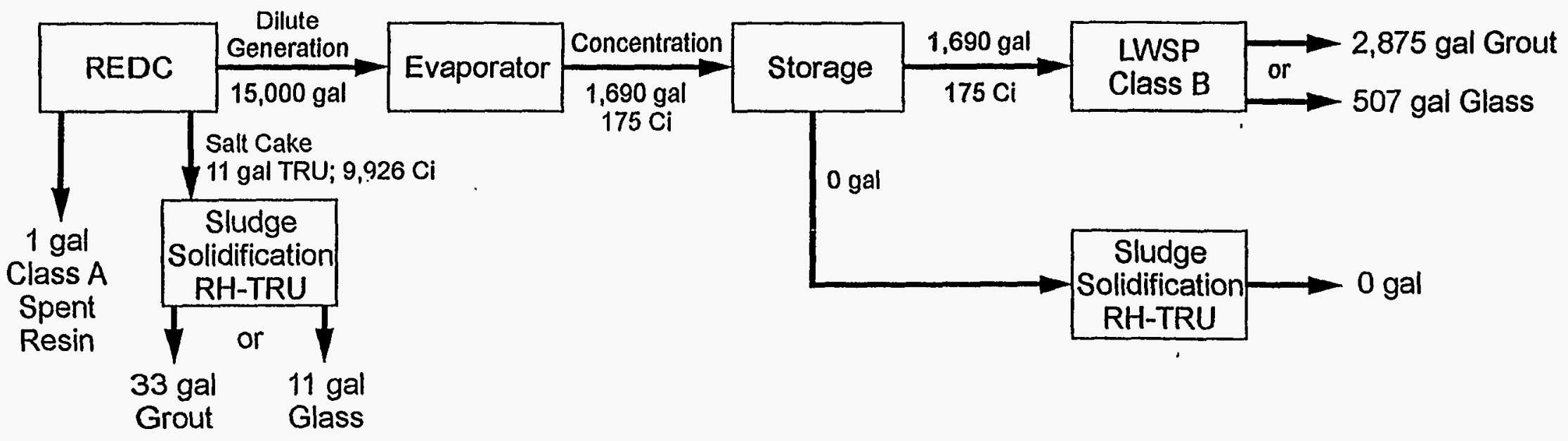

Fig. 1. Annual REDC waste generation rates. 


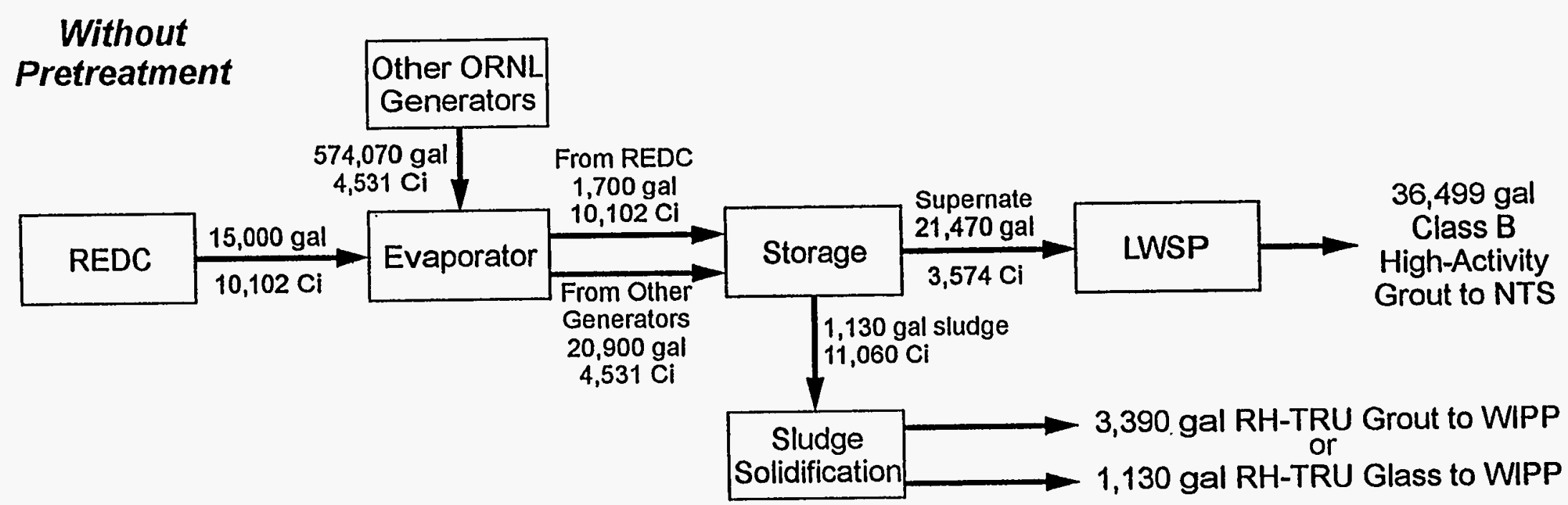

u

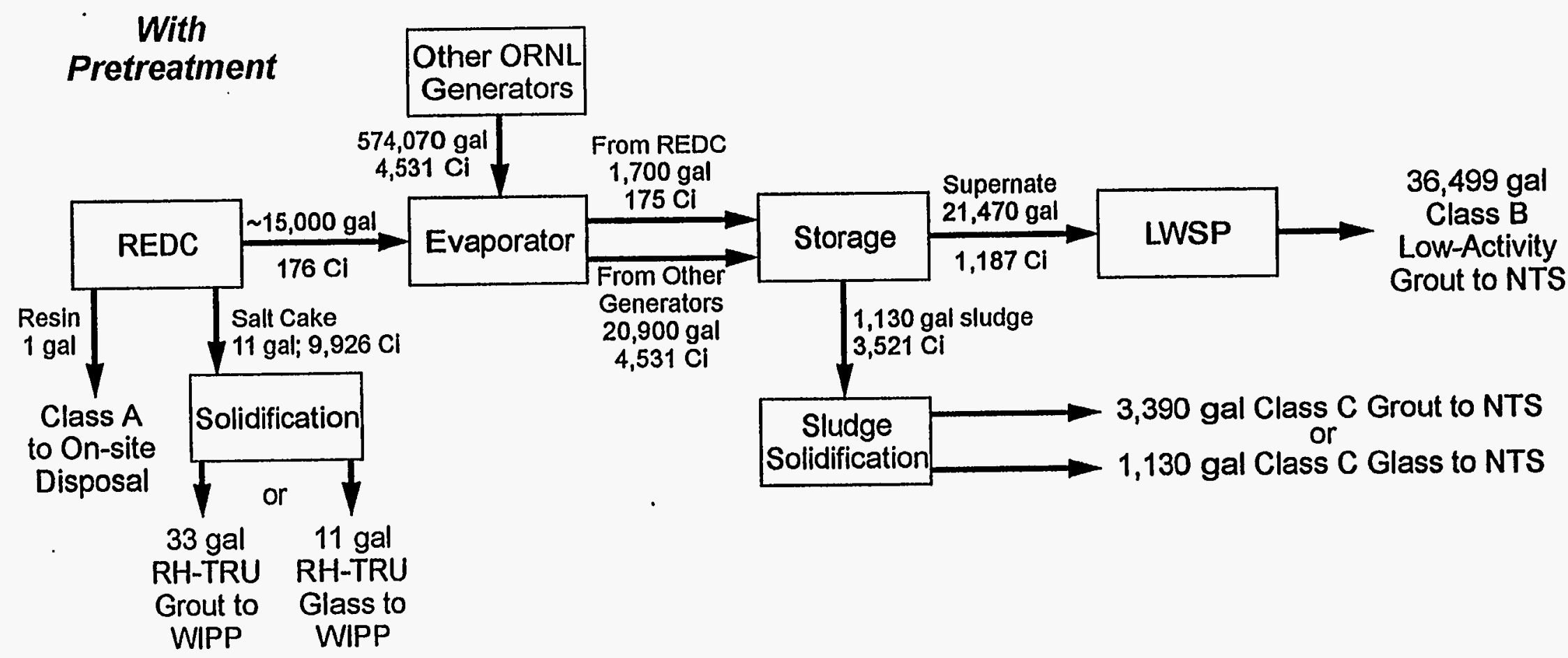

Fig. 2. Annual ORNL LLLW generation rates-with and without pretreatment at REDC. 
- Unit cost estimates are estimated as follows:

- Treating RH-TRU sludge is based on a cost of $\$ 150 \mathrm{M}$ to treat $200,000 \mathrm{gal}$, or $\$ 525$ per gal based on TRU Program estimates for private sector treatment.

- Treating Class A resins or low-activity Class B supernates is based on LWSP costs of $\$ 2.5 \mathrm{M}$ per $50,000 \mathrm{gal}$ of waste treated, or $\$ 50$ per gal.

- Treating high-activity Class B or Class C waste is estimated at three times LWSP costs.

- On-site storage costs are estimated at $\$ 203 / \mathrm{ft}^{3}$, or $\$ 1100$ per drum filled with $40 \mathrm{gal}$ of Class B solidified waste (disposal costs for the Interim Waste Management Facility).

- On-site storage costs are estimated to be $\$ 9200$ per drum containing 40 gal of Class C or RH-TRU solidified waste ( $\$ 1.1 \mathrm{M}$ for 24 below-grade storage wells that will hold a maximum of 120 drums).

- Shipping container costs are estimated as

- $\quad \$ 700$ per drum for 55-gal DOT-certified stainless steel drums;

- $\quad$ \$150K per LWSP for low-activity Class B waste and \$450K per LWSP for high-activity Class B waste (an LWSP generates 60 liners containing 1400 gal solidified waste each);

- $\quad$ \$10K per canister for RH-TRU waste (a canister holds three 55-gal drums containing 40 gal of solidified waste each); ${ }^{2}$

- $\quad \$ 1.6 \mathrm{M}$ per cask for RH-TRU waste; two casks are required for a significant number of shipments. ${ }^{2}$

- Transportation costs are estimated to be $\$ 600 \mathrm{~K}$ per LWSP for low-activity Class B waste and three times that for high-activity Class B or Class C waste for disposal at the Nevada Test Site.

- Transportation costs are estimated to be \$11K per canister for RH-TRU waste for disposal at the WIPP. ${ }^{2}$

- Disposal costs in this analysis are limited to emplacement costs only for off-site disposal. It is assumed that disposal costs will be paid for by other programs. In a true life-cycle cost analysis, these costs would have to be considered. If total disposal costs were considered, the results would be more favorably inclined toward pretreatment because of the high cost of repository disposal for relatively large volumes of RH-TRU wastes generated by the "no-pretreatment" cases.

- Disposal costs for the Nevada Test Site are estimated to be $\$ 250 \mathrm{~K}$ per LWSP for low-activity Class $\mathbf{B}$ waste and three times that for high-activity and Class $\mathbf{C}$ waste.

- Disposal costs for WIPP are estimated to be \$3450 per canister for RH-TRU waste. ${ }^{2}$

- On-site storage costs are estimated at $\$ 203 / \mathrm{f}^{3}$ or $\$ 1100$ per drum filled with 40 gal of Class A solidified waste, assuming disposal costs for the Interim Waste Management Facility.

- On-site storage, transportation, and disposal costs for RH-TRU salt cake at a highlevel waste repository are assumed to be the same as those for RH-TRU sludges at WIPP. 


\section{RESULTS}

The results of this analysis can be summarized as follows:

- See the "boxes" on the right margin of Table 2. See also the present-worth calculations shown in Table 3.

- The life-cycle costs for ORNL LLLW with and without REDC pretreatment can be summarized as follows:

- Total cost of treating 16-year ORNL waste accumulation without REDC pretreatment

- $\quad \$ 157.7$ million using grout treatment

- $\quad \$ 141.3$ million using glass treatment

- . Present-worth expenditures (discount rate of $7 \%$ ) are $\$ 72.3$ million and $\$ 66.8$ million, respectively

- Total cost of treating 16-year ORNL waste accumulation with REDC pretreatment

- $\quad \$ 97.8$ million using grout treatment

- $\quad \$ 88.0$ million using glass treatment

- $\quad$ Present-worth expenditures (discount rate of 7\%) are $\$ 56.3$ million and $\$ 53.0$ million, respectively

The big discriminators must also be considered:

- Large relative costs for treating large volumes of high-activity Class B supernate for "no-pretreatment" case as compared with low-activity Class B supernate for "pretreatment" case.

- Large shipping containers and transportation costs for large volumes of RH-TRU waste that must be transported for "no-pretreatment" cases as compared with large volumes of Class $\mathrm{C}$ waste and small volumes of RH-TRU for "pretreatment" case.

\section{DISCUSSION OF RESULTS}

- When REDC wastes are comingled with other ORNL LLLW, the present-worth treatment and transport costs are higher by a factor of 1.3 for the "no-pretreatment" cases. This result is consistent with data from similar studies conducted at other sites. ${ }^{3,4}$

- The smaller volume of waste generated by vitrification as compared with grout lowers the overall costs. The incentive to solidify newly generated waste in glass is greater if REDC pretreatment is not implemented since smaller volumes of RH-TRU would be generated for disposal at WIPP or a high-level repository. 


\begin{tabular}{|c|c|c|c|c|c|c|c|}
\hline & $\cdot$ & & 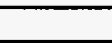 & E & & & \\
\hline & & & & & & & \\
\hline & & \multicolumn{2}{|c|}{ Cost units } & \multicolumn{2}{|c|}{\begin{tabular}{|c|} 
Annual \\
p/o pretreatment $\mathrm{w} /$ pretreatment
\end{tabular}} & \multicolumn{2}{|c|}{ 16-year cumulative } \\
\hline Aetivity or parameter & Entry units & $\mathbf{s}$ & per & D/o pretreatment & \begin{tabular}{|l|l|} 
w/pretreatmeat & \\
\end{tabular} & Who pretereatrént & w/pítreatment \\
\hline Difue LIIW generation & gal & & & 589,070 & 589,070 & $9,425,120$ & $9,425,120$ \\
\hline LILW concentrate & gal & & & 22,600 & 22,600 & 361,600 & 361,600 \\
\hline Ci content (primarily MFP) & $\mathrm{Ci}$ & & & 14,633 & 14,633 & 234,128 & 234,128 \\
\hline \multicolumn{8}{|l|}{ Volumes to be treated for disposal } \\
\hline High-2etivity Class B LILW supermate & gal & & & 21,470 & & 343,520 & \\
\hline Low-ectivity Class B LLLW sopernate & gal & & & & 21,470 & & 343,520 \\
\hline Class A LLW solids & gal & & & & 1 & & 16 \\
\hline \begin{tabular}{|l|l} 
RHF-TRU dry salt cake \\
\end{tabular} & gal & & & & 11 & & 1776 \\
\hline RH-TRU sludge & gal & & & 1,130 & & 18,080 & \\
\hline \begin{tabular}{|l} 
Class C CLW shudge \\
\end{tabular} & gal & & & & 1,130 & & 18,080 \\
\hline \multicolumn{8}{|l|}{ Ci content of waste } \\
\hline Figh-2etivity Class B LILW supernate & $\mathrm{Ci} / \mathrm{gal}$ & & & 0.17 & & 0.17 & \\
\hline Low-2ctivity Class B LLLWW supernate & Cigal & & & & 0.06 & & 0.06 \\
\hline Class A LIW solids & Ci/gal & & & & 0 & & 0 \\
\hline RH-TRU dry salt eake & Cilgal & & & & 902 & & 902 \\
\hline RH-TRU shudge & Cilgal & & & 10 & & 10) & \\
\hline Class C LLW studge & Ciggal & & & & 3 & & 3 \\
\hline \multicolumn{8}{|l|}{ Costs - grout Row sheet } \\
\hline \multicolumn{8}{|l|}{ Treated waste volumes } \\
\hline Figh-activity supernate cement block & gal & & & 36,499 & & 583,984 & \\
\hline Low-2ctivity supecmate cement block & gal & & & & 36,499 & J10 & 583,984 \\
\hline Class A solids cement block & gal & & & & 3 & & 48 \\
\hline RH-TRU elt cake cement block & gal & & & & 33 & & 528 \\
\hline RH-TRU shudge cement block & gal & & & 3,390 & & 54,240 & \\
\hline Class C shudge cement block & gal & & & & 3,390 & & 54,240 \\
\hline \multicolumn{8}{|l|}{ Treameat costs } \\
\hline \begin{tabular}{|l|} 
Pretreatmeat GPP \\
\end{tabular} & $S$ million & & & & 2.000 & & 2.000 \\
\hline Pretreatment expense funding & $S$ million & & & & 4.500 & & 4.500 \\
\hline REDC internsi costs & Smillion & & & 2.000 & 2.000 & 32.000 & 32.000 \\
\hline Solidification high-activity supernate & Smillion & 150 & gal & & & 51.528 & \\
\hline Solidification low-ectivity superante & $S$ million & 50 & gal & & & & 17.176 \\
\hline Solidification Class A solids & Smillion & 50 & gal & & & & 0.001 \\
\hline Solidification RH-TRU sult cake & $\$$ million & 525 & gal & & & & 0.092 \\
\hline Solidification RH-TRU studge & $\$$ million & 525 & gal & & & 9.492 & \\
\hline Solidification Class C sludge & Smillion & 150 & gal & & & & 2.712 \\
\hline \multicolumn{8}{|l|}{ On-site storge costs } \\
\hline LLW storage (Class B) & S million & 1,100 & drum & & & 16.060 & 16.060 \\
\hline RH TRU and Class C stonage & $\$$ million & 9,200 & dnum & & & 12.475 & 12.597 \\
\hline \multicolumn{8}{|l|}{ Shipping container costs } \\
\hline Drums (TRU and Cless A solids) & Smillion & 700 & drum & & & 0.949 & 0.010 \\
\hline Casks (high-2ctivity Class B and C) & \$ million & 7,500 & liner & & & 3.128 & 0.291 \\
\hline Casks (low-ectivity Class B) & $\$$ million & 2,500 & liner & & & & 1.043 \\
\hline Canisters (TRU) & \$million & 10,000 & camister & & & 4.520 & 0.044 \\
\hline Cesks (TRU) & $\$$ million & $1,600,000$ & casik & & & 3.200 & 1.600 \\
\hline \multicolumn{8}{|l|}{ Transportation cosss } \\
\hline Figh-2ectivity Clese B and C Lo NTS & \$million & 30,000 & liner & & & 12.514 & 1.162 \\
\hline Low-2ctivity Cless B to NTS & Smillion & 10,000 & liner & & & & 4.171 \\
\hline RH-TRU to WIPP & $S$ million & 11,000 & canister & & & 4.972 & \\
\hline RH-TRU to FLWW respository & & & & & & & 0.048 \\
\hline \multicolumn{8}{|l|}{ Disposenl costs } \\
\hline Nevade Teat Site (high activity) & S million & 12,600 & liner & & & 5.256 & 0.488 \\
\hline Nevade Teat Site (low activity) & Smillion & 4,200 & iner & & & & 1.752 \\
\hline WTPP (RH-TRU) & $S$ million & 3,450 & canister & & & 1.559 & \\
\hline FLWW respository (RH-TRU) & & & & & & & 0.015 \\
\hline On-Site LLW (Class A) & 5 million & 1.100 & drum & & & & 0.001 \\
\hline Totals (S million) & & & & & & 157.654 & 97.763 \\
\hline
\end{tabular}




\begin{tabular}{|c|c|c|c|c|c|c|c|}
\hline \multicolumn{8}{|c|}{ Table 2 (continued) } \\
\hline & & & & & & & \\
\hline & & & & & & & \\
\hline & & \multicolumn{2}{|c|}{ Cost units } & \multicolumn{2}{|c|}{ Annual } & \multicolumn{2}{|c|}{ 16-year cumulative } \\
\hline Activity or parameter & Entry units & $\$$ & per & w/o pretreatmeat & w/pretrcatment & w/o pretritenent & w/pretreatmeat \\
\hline \multicolumn{8}{|l|}{ Costs - glass fow sheet } \\
\hline Treated waste vohmes & & $\therefore$ & & & & & \\
\hline High-activity supernate cement block & gal & & & 36,499 & - & 583,984 & \\
\hline Low-activity supernate cement bloci & gal & & & & 36,499 & & 583,984 \\
\hline Class A solids glass log & gal & & & & 1 & & 16 \\
\hline RH-TRU salt cake glase log & gal & & & & 11 & & 176 \\
\hline RH-TRU sludge glass log & gal & & & 1,130 & & 18,080 & \\
\hline Clase C shudge glass log & gal & & & & 1,130 & & 18,080 \\
\hline \multicolumn{8}{|l|}{ Treatment costs } \\
\hline Pretreatment GPP & S million & & & & 2.000 & & 2.000 \\
\hline Pretreatment expense funding & $S$ million & & & & 4.500 & & 4.500 \\
\hline REDC internal costs & Smillion & & & 2.000 & 2.000 & 32.000 & 32.000 \\
\hline Solidification high-activity supernate & S million & 150 & gal & & & 51.528 & \\
\hline Solidification low-activity supernste & S million & 50 & gal & & & & 17.176 \\
\hline Solidification Class A solids & S million & 50 & gal & & & & 0.001 \\
\hline Solidification RH-TRU salt cake & S million & 525 & gal & & & & 0.092 \\
\hline Solidification RH-TRU shudge & $S$ million & 525 & gal & & & 9.492 & \\
\hline Solidification Class C sludge & $\$$ million & 150 & gal & & & & 2.712 \\
\hline \multicolumn{8}{|l|}{ On-site storage costs } \\
\hline LLW storage (Class B) & $S$ million & 1,100 & dnum & & & 16.060 & 16.060 \\
\hline RH TRU and Class C storage & $\$$ million & 9,200 & drum & & & 4.158 & 4.199 \\
\hline \multicolumn{8}{|l|}{ Shipping contsinet costs } \\
\hline Drums (IRU and Class A solids) & Smillian & 700 & dinm & & & 0.316 & 0.003 \\
\hline Casks (high-retivity Class B and C) & $S$ million & 7,500 & liner & & & 3.128 & 0.097 \\
\hline Casks (low-ectivity Class B) & Smillion & 2,500 & liner & & & & 1.043 \\
\hline Canisters (TRU) & 5 million & 10,000 & canister & & & 1.507 & 0.015 \\
\hline Casks (IRU) & Smillion & $1,600,000$ & casi & & & 3.200 & 1.600 \\
\hline \multicolumn{8}{|l|}{ Transportation costs } \\
\hline High-activity Cless B and C to NTS & Smillion & 30,000 & liner & & & 12.514 & 0.387 \\
\hline Low-activity Chess C to NTS & $S$ million & 10,000 & liner & & & & 4.171 \\
\hline RH-TRU to WIPP & S million & 11,000 & canister & & & 1.657 & \\
\hline RH-TRU to HLW repository & S million & 11.000 & canister & & & & 0.016 \\
\hline \multicolumn{8}{|l|}{ Disposel costs } \\
\hline Nevade Test Site (high activity) & S million & 12,600 & liner & & & 5.256 & 0.163 \\
\hline Nevade Test Site (low activity) & S million & 4,200 & Iiner & & & & 1.752 \\
\hline WIPP (RH-TRU) & $S$ million & 3,450 & canister & & & 0.520 & \\
\hline HLW repository (RH-TRU) & S million & 3,450 & canister & & & & 0.005 \\
\hline On-site LLW (Class A) & $S$ million & 1,100 & drum & & & & 0.000 \\
\hline Totals ( $\$$ million) & & & & & & 141336 & 87.992 \\
\hline
\end{tabular}


Table 3. Present-worthed expenditures for management of ORNL LLLW, as of March 8, 1995: comparison of current operation with waste pretreatment operations at REDC ${ }^{3, b}$

\begin{tabular}{|c|c|c|c|c|c|c|c|c|c|}
\hline \multirow[b]{3}{*}{ Year } & \multirow[b]{3}{*}{$\begin{array}{c}P W \\
\text { factor }\end{array}$} & \multicolumn{4}{|c|}{ Without pretreatment } & \multicolumn{4}{|c|}{ With pretreatment } \\
\hline & & \multicolumn{2}{|c|}{ Grout } & \multicolumn{2}{|c|}{ Glass } & \multicolumn{2}{|c|}{ Grout } & \multicolumn{2}{|c|}{ Glass } \\
\hline & & $\begin{array}{c}\text { Waste } \\
\text { mgt. } \\
\text { operation }\end{array}$ & $\begin{array}{l}\text { Waste } \\
\text { treatment }\end{array}$ & $\begin{array}{c}\text { Waste } \\
\text { mgt } \\
\text { operation }\end{array}$ & $\begin{array}{c}\text { Waste } \\
\text { treatment }\end{array}$ & $\begin{array}{c}\text { Waste } \\
\text { mgt } \\
\text { operation }\end{array}$ & - Waste & $\begin{array}{c}\text { Waste } \\
\text { mgt } \\
\text { operation }\end{array}$ & $\begin{array}{c}\text { Waste } \\
\text { treatment }\end{array}$ \\
\hline 0 & 1.000 & & & & & & 6.500 & & 6.500 \\
\hline 1 & 0.935 & 1.869 & & 1.869 & & 1.869 & & 1.869 & \\
\hline 2 & 0.873 & 1.747 & & 1.747 & & 1.747 & & 1.747 & \\
\hline 3 & 0.816 & 1.633 & & 1.633 & & 1.633 & & 1.633 & \\
\hline 4 & 0.763 & 1.526 & & 1.526 & & 1.526 & & 1.526 & \\
\hline 5 & 0.713 & 1.426 & & 1.426 & & 1.426 & & 1.426 & \\
\hline 6 & 0.666 & 1.333 & & 1.333 & & 1.333 & & 1.333 & \\
\hline 7 & 0.623 & 1.245 & & 1.245 & & 1.245 & & 1.245 & \\
\hline 8 & 0.582 & 1.164 & & 1.164 & & 1.164 & & 1.164 & \\
\hline 9 & 0.544 & 1.088 & & 1.088 & & 1.088 & & 1.088 & \\
\hline 10 & 0.508 & 1.017 & & 1.017 & & 1.017 & - & 1.017 & \\
\hline 11 & 0.475 & 0.950 & & 0.950 & & 0.950 & & 0.950 & \\
\hline 12 & 0.444 & 0.888 & & 0.888 & & 0.888 & & 0.888 & \\
\hline 13 & 0.415 & 0.830 & & 0.830 & & 0.830 & & 0.830 & \\
\hline 14 & 0.388 & 0.776 & & 0.776 & & 0.776 & & 0.776 & \\
\hline 15 & 0.362 & 0.725 & & 0.725 & & 0.725 & & 0.725 & \\
\hline \multirow[t]{2}{*}{16} & 0.339 & 0.677 & 70.857 & 0.677 & 47.875 & 0.677 & 30.913 & 0.677 & 27.604 \\
\hline & & 18.893 & 70.857 & 18.893 & 47.875 & 18.893 & 37.413 & 18.893 & 34.104 \\
\hline Totals & & \multicolumn{2}{|c|}{89.750} & \multicolumn{2}{|c|}{66.769} & \multicolumn{2}{|c|}{56.306} & \multicolumn{2}{|c|}{52.997} \\
\hline
\end{tabular}

2Assuming that REDC LLLW discharges are comingled with other ORNL LLLW.

Discount factor $=0.07$. 


\section{RECOMMENDATTON}

Based on the information presented in this analysis, our recommendation is to proceed with REDC treatment projects.

\section{REFERENCES}

1. Feasibility Study for Processing ORNL Transurainic Waste in Existing and Modified Facilities - Management Summary, prepared by Parallax, Inc., Oak Ridge, TN, September 1995.

2. WHPP Feasibility Study, prepared by Lee Wan \& Associates, Inc., 1988.

3. System Requirements Review Hanford Tank Waste Remediation System - Final Report, prepared by Office of Hanford Waste Management Operations, U.S. Department of Energy, April 1995.

4. Tank Remediation Plans and Activities at Idaho National Engineering Laboratory, prepared by James Murphy, February 1995. 
. . .

$\cdot$ 
ORNL/TM-13433

\section{INTERNAL DISTRIBUTION}

1. J. S. Baldwin

2. W. D. Bond

3. A. G. Croff

4. S. M. DePaoli

5. T. E. Kent

6. B. E. Lewis, Jr.

7. R. C. Mason

8. C. P. McGinnis

9. L. E. McNeese

10. T. H. Monk

11. B. D. Oakley

12. B. D. Patton

13-17. S. M. Robinson

18. S. T. Rudell

19. C. B. Scott

20. R. M. Wham

21. T. D. Welch

22. Central Research Library

23. Laboratory Records - RC

24-25. Laboratory Records for submission to OSTI

\section{EXTERNAL DISTRIBUTION}

26. S. M. Gibson, U.S. Department of Energy, Oak Ridge Operations, 3 Main Street, Oak Ridge, TN 37830

27. F. J. Homan, Molten Metal Technology, Inc., 1009 Commerce Park Drive, Oak Ridge, TN 37830

28. J. R. Noble-Dial, U.S. Department of Energy, Oak Ridge Operations, 3 Main Street, Oak Ridge, TN 37830

29. G. L. Riner, U.S. Department of Energy, Oak Ridge Operations, 3 Main Street, Oak Ridge, TN 37830

30. Bryan Westich, U.S. Department of Energy, Oak Ridge Operations, 3 Main Street, Oak Ridge, TN 37830 